\section{To russiske leger forteller}

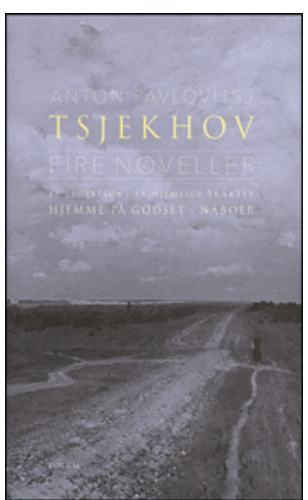

\section{Anton Pavlovitsj Tsjekhov \\ Fire noveller}

Et legebes $\varnothing k$ - På hjemlige trakter - Hjemme på godset - Naboer. 96 s. Oslo: Solum forlag, 2013. Pris NOK 286

ISBN 978-82-560-1747-8
I sin spalte i Frankfurter Allgemeine Zeitung ble litteraturkritikeren Marcel Reich-Ranicki (1920-1913) spurt av en leser hva han ville anbefale henne av Tsjekhov. Av hans «vidunderlige, korte historier», svarte kritikeren lakonisk, burde hun lese «Alle. Ja, jeg mener det alvorlig: alle».

Anton Pavlovitsj Tsjekhov (1860-1904), utdannet lege i Moskva i 1884 og død av tuberkulose i Tyskland i 1904, har et så omfattende forfatterskap at man ikke riktig forstår at han ved siden av sine skuespill, flere hundre fortellinger, 4000 brev og reisen gjennom Sibir til straffeleirene på Sakhalin, også virket som lege. Men det gjorde han. I perioder med en arbeidsdag som virker overveldende - konsultasjoner, arbeid under en koleraepidemi, forebyggende arbeid, samfunnsmedisin; og i tillegg grunnla han klinikker, skoler, biblioteker. Under medisinstudiet skrev han ca. 200 fortellinger og forsørget ikke bare seg selv, men hele storfamilien. Det fortsatte han med, i varierende grad, resten av livet. Hans fortellinger fra studietiden er korte, dagsskisser for aviser og tidsskrifter, ofte preget av en burlesk humor, som senere kommer i bakgrunnen.

I Tsjekhovs mer modne noveller er humor ofte til stede, men mer som et ettertenksomt, vemodig trekk. Det typiske for hans noveller er at de, tilsynelatende enkelt fortalt, krever en meddiktning som gjør at man forstår Hemingways begeistring da han ble kjent med novellene i Paris i 1920-årene. Enda så forskjellige de to forfatterne er, har de som novellister blant annet det til felles at fortellingene ikke ender et spesielt sted. Slutten er, som begynnelsen, åpen. De inneholder ikke mer fasit og sluttstrek enn det livet gjør.

Det er derfor all grunn til å være både Solum forlag og oversetteren Erling Sande takknemlig for dette tilskuddet av Tsjekhov-noveller i norsk språkdrakt. De tilhører den siste delen av forfatterskapet, skrevet i 1890-årene. En av dem skildrer nettopp et legebesøk. Ifølge forlaget handler novellene om kvinner og konvensjoner. Men man kan trygt si at de handler om mennesker og konvensjoner. Noen holdes, noen brytes, men hvor lykken er, har ikke Tsjekhov tenkt å fortelle oss. Den siste novellen, Naboer, er typisk for siste del av hans forfatterskap. Den er poetisk og den har humor, men hva som er riktig og hva som er galt, er ikke like tydelig ved slutten av fortellingen som man kan tro ved begynnelsen.

\section{Bulgakov}

Nesten samtidig med Tsjekhov-novellene ble en annen russisk lege og forfatter, Mikhail Bulgakov (1891-1940) utgitt på norsk. En ung leges opptegnelser handler nettopp om det som tittelen sier, om et

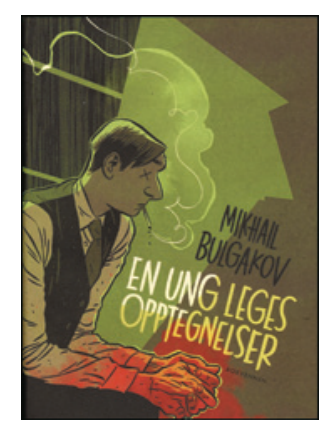

Mikhail Bulgakov

\section{En ung leges opptegnelser}

204 s. Oslo: Bokvennen forlag, 2013.

Pris NOK 349

ISBN 978-82-7488-381-9

legeliv, eller rettere, om ett år av det. Når man leser denne novellesamlingen etter Tsjekhov, eller før, kan man tro at det var Bulgakov som virket som lege og samtidig skrev, mens Tsjekhov var forfatter som var utdannet lege. Det er omvendt. Tsjekhov arbeidet med medisin så lenge han kunne, Bulgakov bare en kort periode. Ferdig utdannet ved universitetet $\mathrm{i}$ Kiev våren 1916 ble Bulgakov i sep-

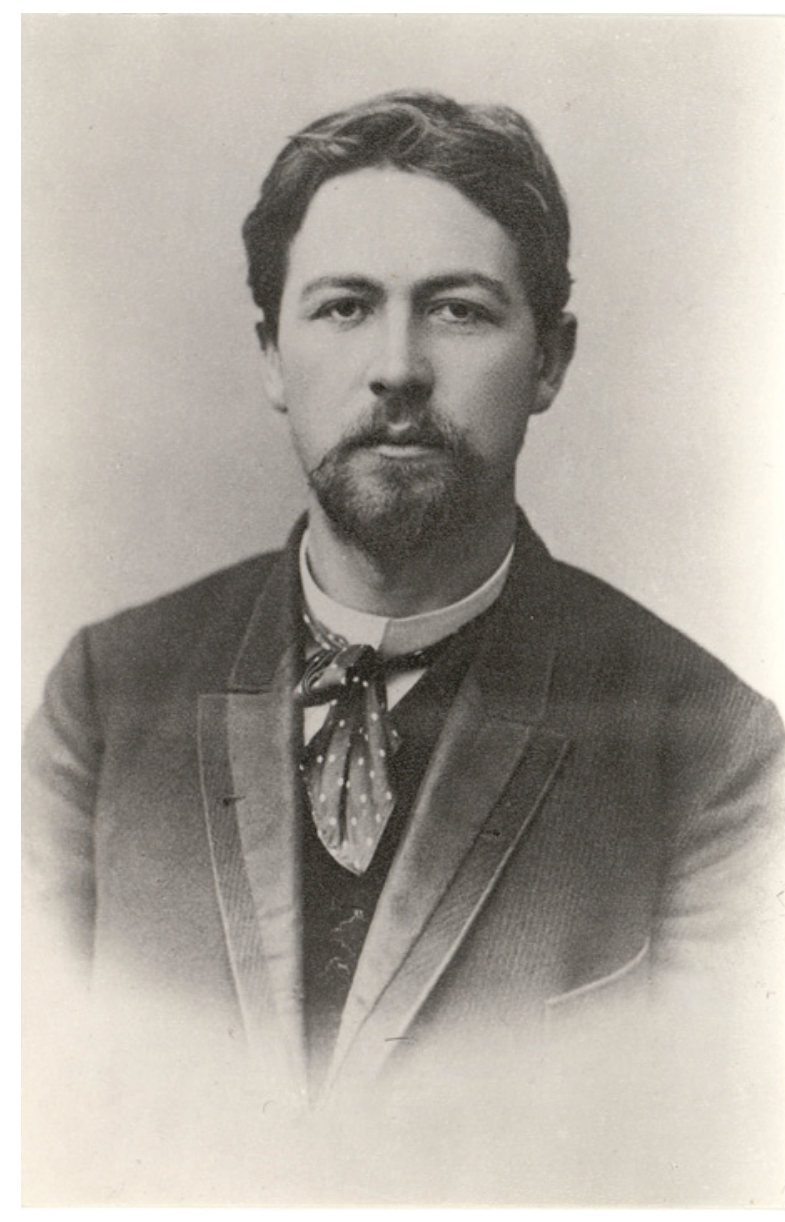

Anton Pavlovitsj Tsjekhov. Foto: Wikimedia Commons 
tember beordret til en liten landsby $120 \mathrm{~km}$ fra Moskva, der han skulle virke som distriktslege. Det var krig, og de erfarne legene var ved fronten. Til stillingen $\mathrm{i}$ landsbyen hørte en sykestue med operasjonssal og ansvar for fødsler. Fødsler og brokk, brokk og fødsler. Og noen fryktelige ulykker. Det var alltid noe å grue seg til. Og når han støtte på tilstander som han ikke riktig visste hvordan skulle behandles, trøstet jordmødrene og feltskjæren ham med hvor dyktig hans forgjenger, Leopold Leopoldvitsj, hadde vært. Det var ikke stor trøst $\mathrm{i}$ å høre at «han opererte fra morgen til kveld».

Fortellingene ble publisert i tidsskrifter i perioden 1925-27. Først i 1963 ble de funnet frem igjen og utgitt som bok. Bulgakov skrev og skrev, romaner, fortellinger og skuespill, uten å få nesten noe utgitt i Stalins Sovjet. Hans udiskutable mesterverk, romanen Mesteren og Margarita, utkom lenge etter hans død.

En ung leges opptegnelser inneholder ni noveller. De første sju henger sammen som fortellingssyklus, og de forteller om en hverdag som kan minne de fleste av oss om den frykten vi kunne oppleve da vi begynte å arbeide i sykehus. Men det er lenge siden en ung lege ble stilt alene overfor den type oppgaver jeg-fortelleren møter her. Den åttende har også et selvbiografisk preg, men en annerledes tone. Den handler om misbruk, og er etter mitt skjønn den svakeste. Etter en skade ble Bulgakov selv morfinist, men i 1918 klarte han å komme ut av misbruket.

Den siste fortellingen har igjen et helt annet preg. Også den er lagt i munnen på en lege, men fortellerstemmen og stemningen er som i Bulgakovs borgerkrigsskildring fra Kiev, romanen Den hvite garde. Den viser et dilemma, men ikke en leges dilemma, mer et generelt menneskelig.

Også hos Bulgakov er det humor - og gru. Den som selv har stått overfor vanskelige og viktige kliniske avgjørelser uten støtte i utdanning eller kolleger, vet godt at det Bulgakov forteller, ikke først og fremst er morsomt. Selv om det kan høres slik ut.

Bulgakovs novellesamling er oversatt av kollega Per Joachim Lund (f. 1928) til et lettlest og flytende norsk. Jeg kan ikke sammenlikne den norske versjonen med den russiske originalen, men Lund tåler godt å bli sammenliknet med de tyske og engelske oversettelsene (1). Han har utført en bedrift. Skulle jeg pirke på noe, måtte det være at tittelen på en av novellene, En snuoperasjon, blir for enkel i forhold til det det dreier seg om. Den engelske oversettelse Baptism by rotation sier mer om det å snu et foster som ligger i tverrleie, når du ikke har gjort det før og er den eldste i rommet. I en slik situasjon er uttrykket «en dåp» passende.

Bøkene er små og hendige med godt trykk. Disse to korte novellesamlingene kan jeg anbefale på det varmeste.

\section{Per E. Børdahl}

Høvik

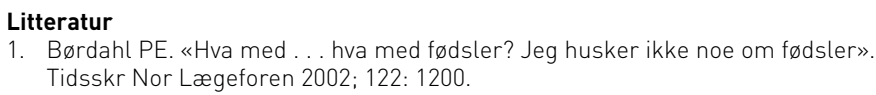

\section{Å lykkes}

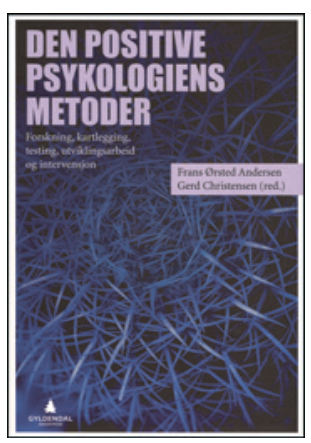

Frans Ørsted Andersen, Gerd Christensen, red. Den positive psykologiens metoder

Forskning, kartlegging, testing, utviklingsarbeid og intervensjon. 259 s, ill. Oslo: Gyldendal Akademisk, 2013 Pris NOK 385 ISBN 978-82-05-45354-8

Positiv psykologi er et relativt nytt praksis- og forskningsfelt som fokuserer på «optimal menneskelig funksjon» snarere enn på psykopatologi og funksjonssvikt. Talsmennene for denne faglige retningen betrakter metoden som et supplement til eksisterende forståelser og metoder, og gjør ikke krav på å ha etablert et selvstendig paradigme.

Denne utgivelsen (dansk original fra 2012) er primært ment som en grunnbok for masterstudenter i positiv psykologi, men også som en lærebok i psykologifaget ved lærer-, sosionom- og sykepleierutdanningene.

Redaktørene har sluppet til forfattere som utdyper ulike begreper og elementer fra positiv psykologi. «Flyt» beskrives som et mentalt område der vi fungerer (mestrer) optimalt, midt mellom overutfordring og underutfordring, med en opplevelse av fordypning, konsentrasjon, selvforglemmelse og positivt engasjement. Fordi flyt betraktes som gunstig for læring og utvikling, vil metodene i positiv psykologi ofte tilstrebe en slik tilstand. I positiv psykologi snakker man ikke om behandlere, men om mentorer og coacher. Ett kapittel fordyper seg i dyader, linjer og nettverk av relasjoner mellom mentor og protesje (mottaker av mentoring). Et annet forklarer hva som kjennetegner coaching, med aktiv lytting, virkningsfulle spørsmål, verdikartlegging og øvelser med prioritering, mål og tiltak. Metoder for kartlegging av individuelle styrker, men også barrierer for positiv utvikling blir presentert. Som et slags korrektiv til den muligens noe overdrevne troen på individets iboende muligheter for egenrealisering og lykke har redaktørene også gitt plass til tre kapitler som presenterer ulike sider ved den såkalte kritiske psykologien, som også trekker inn individets sosiale og materielle omstendigheter/begrensninger. En av bokens redaktører (Gerd Christensen) avslutter da også med en advarsel mot å påføre mennesker med begrensede muligheter nye nederlag ved å mislykkes i å lykkes.

Boken gir en god innføring i det som kjennetegner positiv psykologi som fagfelt, både klinisk og forskningsmessig. For en generelt interessert helsearbeider som ikke skal forske spesifikt innenfor dette feltet, blir det imidlertid litt for mye irrelevant stoff. Kapitlene som omhandler kritisk psykologi, særlig de to første, er dessuten preget av et unødvendig teoretisk språk, som for eksempel «Felles for begrepene og bruken av dem er også at det er den utforskede praksisen og prosjektets interesser som kaller inn relevante begreper»».

Det er vanskelig å anbefale boken til andre enn dem som har ambisjoner om å sette seg inn i forskningsmetoder brukt innenfor positiv psykologi.

Ingvar Bjelland

Klinikkoverlege, Klinikk psykisk helsevern for barn og unge

Haukeland universitetssykehus 